\title{
Assessment of $p$-cresol and phenol antifungal interactions in an arthropod defensive secretion: the case of an endemic Balkan millipede, Apfelbeckia insculpta (L. Koch, 1867) (Diplopoda: Callipodida)
}

\author{
Оџенка фунгиџидных взаимодействий $p$-крезола и фенола в \\ защитном секрете чиенистоногого: пример эндемичной \\ балканской дипмоподы Apfelbeckia insculpta (L. Koch, 1867) \\ (Diplopoda: Callipodida)
}

\section{Bojan Ilić*, Nikola Unković, Danica Ćoćić, Jelena Vukojević, Milica Ljaljević Grbić, Slobodan Makarov Боян ИАич*, Никола Ункович, Аанища Чочич, Елена Вукойевич, Милица Аьяльевич Грбич, Слободан Макаров}

University of Belgrade, Faculty of Biology, Studentski Trg 16, 11000 Belgrade, Serbia. Email: bojan.ilic@bio.bg.ac.rs

KEY WORDS: allomones, antimycotics, checkerboard method, millipede, phenolics.

КЛЮЧЕВЫЕ СЛОВА: алломоны, антимикотики, шахматный метод, двупарноногие многоножки, фенолики.

ABSTRACT. Millipedes (Diplopoda) are a group of arthropods that produce and deploy chemically diverse exudates from defensive glands in the event of predator attack. These exocrine secretions are also potent antimicrobials. In view of the fact that the defensive secretion of the endemic Balkan millipede, Apfelbeckia insculpta (L. Koch, 1867) consists of only two compounds with known antifungal properties ( $p$-cresol and phenol), it represents an ideal model for studying the contribution of individual compounds to the overall antifungal activity of this natural product, thereby enabling us to define the nature and type of interactions between the main compound ( $p$-cresol) and the trace compound (phenol). Twenty-five combinations of concentrations, ranging from 0.1 to $1.0 \mathrm{mg} \mathrm{mL}^{-1}$, were tested on 14 filamentous fungi belonging to the genera Aspergillus, Cladosporium, Fusarium, Penicillium and Trichoderma; two yeasts (Sporobolomyces roseus and Meyerozyma guilliermondii); and one yeast-like filamentous fungus (Aureobasidium pullulans var. melanogenum) using the checkerboard method. Among the 29 interactions observed, the tested combinations of concentrations showed mainly additive (16 instances) and, to a lesser extent, indifferent (12 instances) properties, with notably 2-8 times lower concentrations of compounds needed to suppress fungal growth than those recorded for the individual compounds. A synergistic effect was observed only for Aspergillus niger when $0.1 \mathrm{mg} \mathrm{mL}^{-1}$ of $p$-cresol was supplemented with $0.2 \mathrm{mg}$ $\mathrm{mL}^{-1}$ of phenol. Furthermore, A. niger was the only fungus where all three types of documented antifungal interactions, i.e., synergism, additivism and indifference, were observed. No antagonism between compounds was documented in any of the tested combinations. Meyerozyma guilliermondii was the only tested fungus where no interactions could be determined (MIC $>1.0 \mathrm{mg} \mathrm{mL}^{-1}$ ).

How to cite this article: Ilić B., Unković N., Ćoćić D., Vukojević J., Ljaljević Grbić M., Makarov S. 2020. Assessment of $p$-cresol and phenol antifungal interactions in an arthropod defensive secretion: the case of an endemic Balkan millipede, Apfelbeckia insculpta (L. Koch, 1867) (Diplopoda: Callipodida) // Arthropoda Selecta. Vol.29. No.4. P.413-418. doi: 10.15298/ arthsel. 29.4.03

PЕЗЮМЕ. Двупарноногие многоножки (Diplopoda) - это группа членистоногих, производящая и выделяющая разнообразные химические эксудаты из защитных желез в случае атаки хищника. Эти экзокринные выделения одновременно являются и потенциальными антимикробными агентами. Поскольку защитный секрет эндемичного балканского вида Apfelbeckia insculpta (L. Koch, 1867) состоит лишь из двух компонент с известными противогрибковыми свойствами ( $p$-крезол и фенол), он представляет собой идеальную модель для изучения вклада отдельных компонент в общую фунгицидную активность этого натурального продукта, тем самым позволяя нам определить природу и тип взаимодействий между главной ( $p$-крезол) и следовой компонентами (фенол). В 25 комбинаци- 


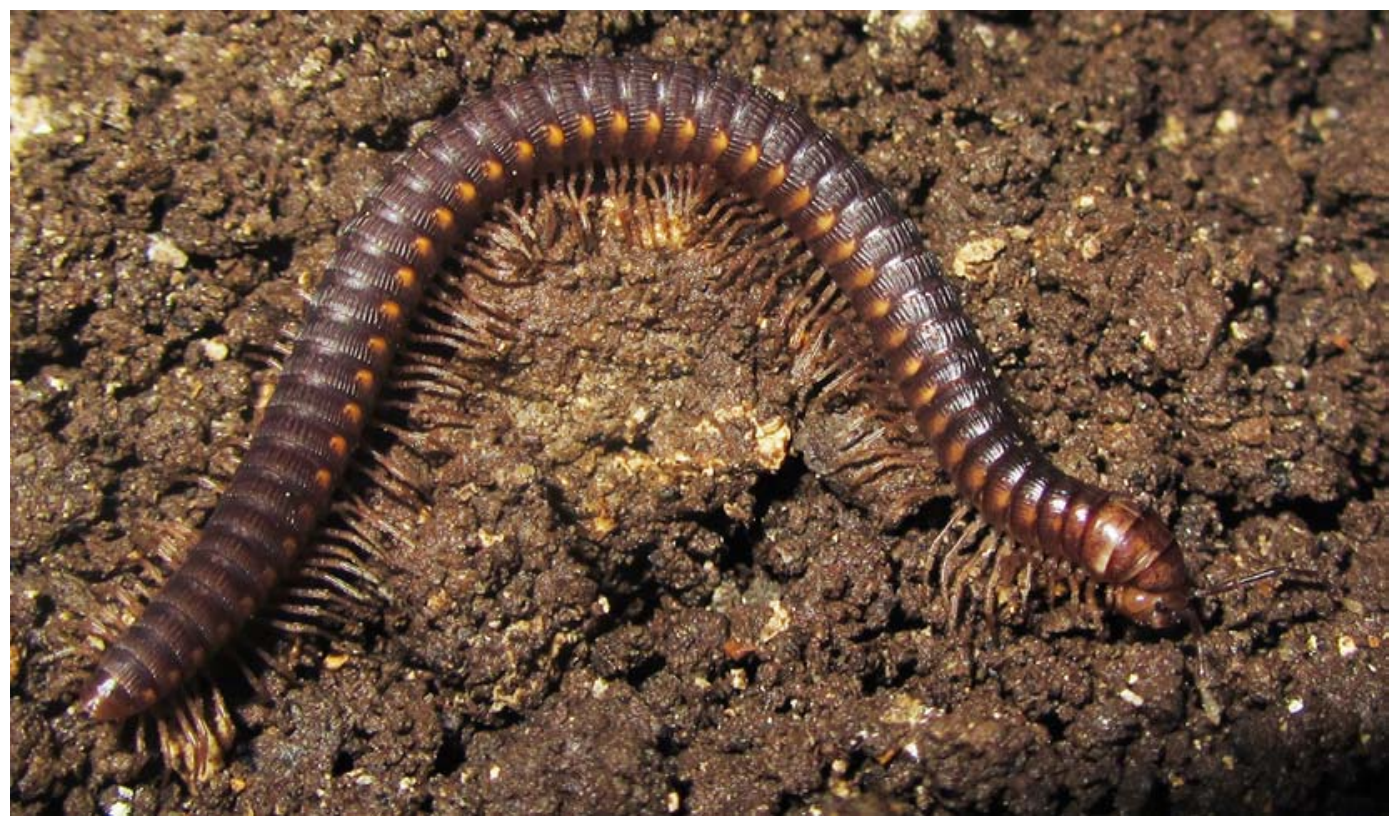

Figure. Habitus of Apfelbeckia insculpta (L. Koch, 1867).

Рисунок. Общий вид Apfelbeckia insculpta (L. Koch, 1867).

ях их концентраций, от 0,1 до 1,0 мг/мл, шахматным методом было проверено действие секрета на 14 видов мицелиальных грибков родов Aspergillus, Cladosporium, Fusarium, Penicillium и Trichoderma, два вида дрожжей (Sporobolomyces roseus и Meyerozyma guilliermondii) и один вид похожего на дрожжи мицелиального грибка (Aureobasidium pullulans var. melanogenum). Среди 29 наблюдавшихся взаимодействий проверяемые комбинации концентраций, в основном, оказывали аддитивное действие (16 случаев) и в меньшей мере были нейтральны (12 случаев) в концентрациях даже в 2-8 раз ниже требуемых, чтобы подавить рост грибков, чем для отдельных компонент. Синэргический эффект наблюдался только для Aspergillus niger при концентрации 0,1 мг/мл $p$-крезола с добавкой 0,2 мг/мл фенола. Более того, A. niger был единственным из грибков, где проявились все три типа документированных фунгицидных взаимодействий, т.е. синэригизм, аддитивизм и нейтральность. Антагонизм не был выявлен ни в одной из тестируемых комбинаций компонент. Вид Meyerozyma guilliermondii был единственным тестируемым грибком, где не выявлено никаких взаимодействий (MIC >1,0 мг/ мл).

\section{Introduction}

In contrast to faster moving and much more aggressive predators, organisms with a limited range of movement or limited control over their movements are usually well defended chemically [Berenbaum, 1995]. Many arthropod groups are included in the ranks of these organisms. Among arthropods that rely on chem- ical defence, millipedes (Diplopoda) are regarded as particularly "accomplished chemists" [Makarov, 2015; Shear, 2015; Ilić et al., 2018].

Besides the thick cuticle hardened by deposits of calcium [Hopkin, Read, 1992; Makarov, 2015], the majority of millipedes possess a serially arranged system of defensive glands (ozadenes), starting from the third or fifth trunk segment [Sierwald, Bond, 2007; Koch, 2015; Makarov, 2015; Shear, 2015]. Millipede defensive glands are places of production and storage of a wide range of chemical compounds - heterocyclic nitrogen-containing compounds, terpenes, benzoquinones and hydroquinones, fatty acid esters, various aliphatic compounds, phenolics and cyanogenic compounds [Makarov, 2015; Shear, 2015]. Among the Helminthomorpha, it is presumed that the phenolic defensive system is the oldest one [Rodriguez et al., 2018]. Although members of the order Callipodida are regarded as "phenolic" millipedes (sensu Eisner et al., 1978) because these millipedes rely exclusively on phenolic allomones [Ilić et al., 2019 and references therein], phenolics can also be found in the defensive secretions of members of other millipede orders, e.g., Polydesmida and Julida [Makarov, 2015; Shear, 2015].

Three phenolic compounds have been so far recorded in callipodidan defensive secretions: $p$-cresol, phenol and $p$-ethylphenol [Ćurčić et al., 2009; Shear et al., 2010; Makarov et al., 2011; Ilić et al., 2019]. A common feature of all screened callipodidan defensive secretions is that $p$-cresol is the only or dominant compound. For example, $p$-cresol constitutes $99 \%$ of the defensive secretion in Apfelbeckia insculpta (L. Koch, 1867) (Figure) [Ilić et al., 2019], while phenol and pethylphenol can be present either as minor or trace 
compounds in other callipodidan defensive gland exudates [Ćurčić et al., 2009; Makarov et al., 2011; Ilić et al., 2019].

Millipede defensive secretions are in most cases bi-, oligo- or multicomponent mixtures. This fact, i.e., the existence of at least two chemical compounds in such gland exudates, is a precondition for different interactions (e.g. synergism or antagonism) between these chemicals. Both compounds that are recorded in the defensive secretion of $A$. insculpta ( $p$-cresol and phenol) are known to possess high bactericidal and fungicidal activity [Murakami et al., 2014; Sabbineni, 2016] and are responsible for the antimicrobial potency of this secretion, which was proven for the first time by Ilić et al. [2019] on a number of pathogenic bacteria, yeasts and filamentous fungi. As this defensive secretion consists of only two compounds, it represents an ideal model on which to study the contribution of individual compounds to the overall antifungal activity of this potent natural product. Here we report for the first time the nature and type of antifungal interactions between the main and trace compounds of the defensive secretion of a callipodidan millipede.

\section{Material and methods}

\section{Chemicals}

Components of the defensive secretion of $A$. insculpta, viz., $p$-cresol ( $\geq 99 \%$ purity) and phenol $(\geq 99 \%$ purity), were obtained from Sigma-Aldrich (Germany). Prior to the experiment, both compounds were dissolved in 30\% ethanol (Zorka Pharma, Serbia).

\section{Tested fungi}

To study the type of interaction between $p$-cresol and phenol in the defensive secretion of $A$. insculpta, we used 14 filamentous fungi (Aspergillus creber BEOFB 3250m, A. flavipes BEOFB $391 \mathrm{~m}$, A. flavus BEOFB $313 \mathrm{~m}$, A. fumigatus BEOFB $321 \mathrm{~m}$, A. niger BEOFB 343m, Cladosporium cladosporioides BEOFB $1821 \mathrm{~m}$, C. uredinicola BEOFB $1841 \mathrm{~m}$, Fusarium verticillioides BEOFB $802 \mathrm{~m}$, Gibberella zeae BEOFB $820 \mathrm{~m}$, Penicillium digitatum BEOFB $1112 \mathrm{~m}$, P. griseofulvum BEOFB $1151 \mathrm{~m}, P$. lanosum BEOFB $1162 \mathrm{~m}, P$. rubens $\mathrm{BEOFB} 1181 \mathrm{~m}$ and Trichoderma citrinoviride BEOFB $1220 \mathrm{~m}$ ), two yeasts (Sporobolomyces roseus BEOFB $4100 \mathrm{~m}$ and Meyerozyma guilliermondii BEOFB $3001 \mathrm{~m}$ ) and one yeast-like filamentous fungus (Aureobasidium pullulans var. melanogenum BEOFB $4200 \mathrm{~m})$. All fungi used in the study came from the culture collection maintained by the Department of Algology, Mycology and Lichenology, Institute of Botany and "Jevremovac" Botanical Garden, University of Belgrade - Faculty of Biology (BEOFB). Prior to the experiment, conidial and yeast cell suspensions of the tested fungi were prepared by washing conidia/cells from the surface of 7-day-old Malt Extract Agar MEA (Lab M Limited, UK) slants with sterile saline solution $(0.9 \% \mathrm{NaCl}$, HemofarmhospitaLogica, Serbia) supplemented with $0.1 \%$ Tween $20(\mathrm{v} / \mathrm{v})$. The final concentration of suspensions was adjusted to 1.0

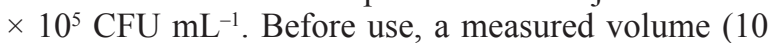
$\mu \mathrm{L})$ of suspensions was cultured on MEA plates to check validity of the inocula and verify the absence of contamination.

\section{Determination of interaction type}

The type of interaction between compounds of the defensive secretion of $A$. insculpta was assessed by the checkerboard method [Schwalbe et al., 2007]. Malt extract broth medium (of the following composition, per litre of deionized water: malt extract, $40 \mathrm{~g}$; $\mathrm{pH}$ 6.8) was distributed into each well of 96-well microplates (F-bottom, Ratiolab). Two-fold serial dilutions of $p$ cresol and phenol were made individually, on two separate plates, with concentrations in the range of from 0.1 to $1.0 \mathrm{mg} \mathrm{mL}^{-1}$. Next, well contents were mixed on a single plate and 25 combinations of concentrations were tested. Suspensions of tested fungi $(10 \mu \mathrm{L})$ were added to each well reaching a final volume of $100 \mu \mathrm{L}$ per well. After $72 \mathrm{~h}$ of incubation at $25 \pm 2{ }^{\circ} \mathrm{C}$ (UE 500, Memmert, Germany), the lowest concentrations without apparent growth observed under a Zeiss Stemi DV4 binocular microscope (Germany) were defined as minimum inhibitory concentrations (MICs) for certain combinations of compounds. The type of interaction (synergism, additivism, indifference or antagonism) of all tested combinations was then determined. The MICs of individual compounds and various tested combinations were transformed into fractional inhibitory concentrations (FIC) according to the following formulas:

$$
\begin{aligned}
& \text { FIC of compound } A=\frac{\text { MIC of compound } A \text { in the presence of compound } B}{\text { MIC of compound } A} \\
& \text { FIC of compound } B=\frac{\text { MIC of compound B in the presence of compound } A}{\text { MIC of compound } B}
\end{aligned}
$$

The fractional inhibitory concentration index (FICi) was calculated from the FIC values for each compound as follows:

$$
\mathrm{FICi}=\mathrm{FICA}+\mathrm{FICB},
$$

where A represents $p$-cresol and B represents phenol in combinations. The combination was considered synergistic when FICi was $\leq 0.5$, additive when FICi was $>0.5-1$, indifferent when FICi was $>1-\leq 4$ and antagonistic when FICi was $>4$ [van Vuuren, Viljoen, 2011].

\section{Results}

The obtained MIC values, transformed into FIC and FICi, were used to define the nature and type of interactions. Individual MICs for $p$-cresol and phenol, MICs of tested combinations with the type of interaction determined and MIC reduction folds are summarized in Table.

With MICs ranging from 0.1 to $0.8 \mathrm{mg} \mathrm{mL}^{-1}, p$ cresol was more potent in inhibiting fungal growth compared to phenol (MICs: 0.1 to $>1.0 \mathrm{mg} \mathrm{mL}^{-1}$ ). In both instances, $P$. digitatum was the most susceptible 
Table. Interaction type in a mixture of $p$-cresol and phenol from the defensive secretion of Apfelbeckia insculpta. Minimum inhibitory concentrations (MICs) are expressed in $\mathrm{mg} \mathrm{mL}^{-1}$. Таблица. Тип взаимодействия в смеси $p$-крезола и фенола из защитного секрета Apfelbeckia insculpta. Минимальнык подавляющие концентрации (MIC) в мг/мл.

\begin{tabular}{|c|c|c|c|c|c|c|c|c|}
\hline \multirow{2}{*}{$\begin{array}{c}\text { Tested } \\
\text { microfungi }\end{array}$} & \multicolumn{2}{|c|}{$\begin{array}{l}\text { MIC of individual } \\
\text { compounds }\end{array}$} & \multicolumn{2}{|c|}{$\begin{array}{c}\text { MIC of compounds in } \\
\text { a mixture }\end{array}$} & \multicolumn{2}{|c|}{ MIC reduction fold } & \multirow[t]{2}{*}{ FICi } & \multirow{2}{*}{$\begin{array}{c}\text { Interaction } \\
\text { type }\end{array}$} \\
\hline & $p$-Cresol & Phenol & $p$-Cresol & Phenol & $p$-Cresol & Phenol & & \\
\hline \multirow{2}{*}{ Aspergillus creber } & \multirow{2}{*}{0.2} & \multirow{2}{*}{0.4} & 0.1 & 0.1 & 2 & 4 & 0.750 & Ad \\
\hline & & & 0.1 & 0.2 & 2 & 2 & 1.000 & Ad \\
\hline \multirow{2}{*}{$\begin{array}{l}\text { Aspergillus } \\
\text { flavipes }\end{array}$} & \multirow{2}{*}{0.4} & \multirow{2}{*}{0.4} & 0.2 & 0.1 & 2 & 4 & 0.750 & Ad \\
\hline & & & 0.2 & 0.2 & 2 & 2 & 1.000 & Ad \\
\hline \multirow{3}{*}{ Aspergillus flavus } & \multirow{3}{*}{0.4} & \multirow{3}{*}{0.8} & 0.2 & 0.1 & 2 & 8 & 0.625 & Ad \\
\hline & & & 0.2 & 0.2 & 2 & 4 & 0.750 & Ad \\
\hline & & & 0.1 & 0.4 & 4 & 2 & 0.750 & Ad \\
\hline \multirow{2}{*}{$\begin{array}{l}\text { Aspergillus } \\
\text { fumigatus }\end{array}$} & \multirow{2}{*}{0.2} & \multirow{2}{*}{0.4} & 0.2 & 0.1 & $\mathrm{wr}$ & 4 & 1.250 & I \\
\hline & & & 0.1 & 0.2 & 2 & 2 & 1.000 & Ad \\
\hline \multirow{3}{*}{ Aspergillus niger } & \multirow{3}{*}{0.4} & \multirow{3}{*}{0.8} & 0.4 & 0.1 & $\mathrm{wr}$ & 8 & 1.125 & I \\
\hline & & & 0.1 & 0.2 & 4 & 4 & 0.500 & $\mathbf{S}$ \\
\hline & & & 0.1 & 0.4 & 4 & 2 & 0.750 & Ad \\
\hline $\begin{array}{l}\text { Aureobasidium } \\
\text { pullulans var. } \\
\text { melanogenum }\end{array}$ & 0.2 & 0.4 & 0.2 & 0.2 & wr & 2 & 1.500 & I \\
\hline $\begin{array}{l}\text { Cladosporium } \\
\text { cladosporioides }\end{array}$ & 0.2 & 0.2 & 0.1 & 0.1 & 2 & 2 & 1.000 & Ad \\
\hline $\begin{array}{l}\text { Cladosporium } \\
\text { uredinicola }\end{array}$ & 0.2 & 0.2 & 0.2 & 0.1 & wr & 2 & 1.500 & $\mathbf{I}$ \\
\hline \multirow{3}{*}{$\begin{array}{l}\text { Fusarium } \\
\text { verticillioides }\end{array}$} & \multirow{3}{*}{0.4} & \multirow{3}{*}{0.8} & 0.4 & 0.1 & $\mathrm{wr}$ & 4 & 1.125 & I \\
\hline & & & 0.2 & 0.2 & 2 & 4 & 0.750 & Ad \\
\hline & & & 0.1 & 0.4 & 4 & 2 & 0.750 & Ad \\
\hline \multirow{3}{*}{ Gibberella zeae } & \multirow{3}{*}{0.4} & \multirow{3}{*}{0.8} & 0.4 & 0.1 & wr & 8 & 1.125 & I \\
\hline & & & 0.2 & 0.2 & 2 & 4 & 0.750 & Ad \\
\hline & & & 0.1 & 0.4 & 4 & 2 & 0.750 & Ad \\
\hline $\begin{array}{l}\text { Meyerozyma } \\
\text { guilliermondii }\end{array}$ & 0.8 & $>1.0$ & - & - & - & - & - & - \\
\hline $\begin{array}{l}\text { Penicillium } \\
\text { digitatum }\end{array}$ & 0.1 & 0.1 & 0.1 & 0.1 & wr & wr & 2.000 & I \\
\hline $\begin{array}{l}\text { Penicillium } \\
\text { griseofulvum }\end{array}$ & 0.1 & 0.2 & 0.1 & 0.1 & wr & 2 & 1.500 & $\mathbf{I}$ \\
\hline $\begin{array}{l}\text { Penicillium } \\
\text { lanosum }\end{array}$ & 0.2 & 0.2 & 0.1 & 0.1 & 2 & 2 & 1.000 & Ad \\
\hline \multirow{2}{*}{ Penicillium rubens } & \multirow{2}{*}{0.2} & 04 & 0.2 & 0.1 & $\mathrm{wr}$ & 4 & 1.250 & I \\
\hline & & 0.4 & 0.1 & 0.2 & 2 & 2 & 1.000 & Ad \\
\hline $\begin{array}{l}\text { Sporobolomyces } \\
\text { roseus }\end{array}$ & 0.4 & 0.2 & 0.2 & 0.2 & 2 & $\mathrm{wr}$ & 1.500 & I \\
\hline Trichoderma & & & 0.1 & 0.1 & wr & 4 & 1.250 & I \\
\hline citrinoviride & 0.1 & 0.4 & 0.1 & 0.2 & wr & 2 & 1.500 & I \\
\hline
\end{tabular}

Ad - additive effect; FICi — fractional inhibitory concentration index; I — indifferent effect; S — synergistic effect; wr — without reduction of MIC value; - - combinations and interactions not determined.

fungus (MIC $0.1 \mathrm{mg} \mathrm{mL}^{-1}$ ), while $p$-cresol also demonstrated the same range of activity against $P$. griseofulvum and T. citrinoviride. With MICs of 0.8 and $>1.0$ $\mathrm{mg} \mathrm{mL}^{-1}$ for $p$-cresol and phenol, respectively, M. guilliermondii was the most resistant tested fungus, followed by $A$. flavus, $A$. niger, $F$. verticillioides and $F$. graminearum (MICs of 0.4 and $0.8 \mathrm{mg} \mathrm{mL}^{-1}$ for $p$ cresol and phenol, respectively).

Due to the fact that the sensitivity of $M$. guilliermondii to phenol was above the tested range of con- centrations ( $\mathrm{MIC}>1.0 \mathrm{mg} \mathrm{mL}^{-1}$ ), no FIC and FICi values could be calculated, and hence no interactions between compounds could be analysed. Among 29 determined interactions, the tested combinations of concentrations showed mainly additive (16 instances: FICi 0.625-1.000) and to a lesser extent indifferent (12 instances: FICi 1.125-2.000) properties, with notably lower concentrations (two to eight times lower) of compounds needed to suppress fungal growth than those recorded for individual MIC values (Table). A syner- 
gistic effect (FICi 0.500) was observed only for $A$. niger when $0.1 \mathrm{mg} \mathrm{mL}^{-1}$ of $p$-cresol was combined with $0.2 \mathrm{mg} \mathrm{mL}^{-1}$ of phenol. Furthermore, A. niger was the only fungus where all three types of documented antifungal interactions, i.e., synergism, additivism and indifference, were observed. Aside from $A$. niger, additive and indifferent effects of the tested compounds were observed for $A$. fumigatus, $F$. verticillioides, $F$. graminearum and $P$. rubens, while the rest of the fungi were characterized by only one type of compound interaction. No antagonism was documented in any of the tested combinations.

\section{Discussion}

The antifungal potential of the defensive secretion of $A$. insculpta and its individual compounds ( $p$-cresol and phenol) was evaluated in several studies to date on a number of pathogenic yeasts (Candida albicans, $C$. krusei, C. tropicalis and C. dubliniensis) and filamentous fungi (Aspergillus fumigatus, A. niger, Cladosporium cladosporioides, C. uredinicola, Fusarium verticillioides, F. graminearum, Penicillium griseofulvum, P. lanosum and P. rubens) [Gallucci et al., 2014; Ilić et al., 2019]. Phenolic compounds ( $p$-cresol and phenol among them) are generally known as potent antimicrobial agents [Gallucci et al., 2014]. Their molecular structure is optimal to permeate cell membranes and alter cellular permeability [Brocca et al., 2013]. Specifically, several molecular properties of phenolics have been linked with their antifungal potential - properties such as lipophilicity, reactivity and ability to form specific interactions between the phenolic compounds and their target receptor in cellular lipoprotein membranes [Dambolena et al., 2012; Gallucci et al., 2014; Pizolitto et al., 2015]. The last mentioned characteristic of phenolic compounds is mirrored by their ability to inactivate microbial adhesins which lead to the leakage of cytoplasmic contents [Velásquez et al., 2019].

Every phenolic compound has different bioactive properties depending on its structure, number of aromatic and hydroxyl groups and their distribution in the structure [Pizolitto et al., 2015]. Both phenolics that are present in the defensive secretion of $A$. insculpta are monohydroxylic compounds, with the difference being that $p$-cresol has an additional methyl group on the fourth carbon atom of the benzene ring. This difference in structure can be seen as the reason for the difference in the level of antifungal activity between phenol and $p$-cresol which was observed in the present study. The general trend observed in our experiment was that the tested fungi are more susceptible to $p$ cresol than to phenol. Alexieva et al. [2008] tested the effects of mixtures of phenol and methyl-substituted phenols $(o-, m-, p$-cresol) on the growth and degradation capacity of Trichosporon cutaneum and showed that $p$-cresol exhibited a stronger toxic effect on this fungal species than did phenol. Our data further corroborate this finding.
However, interactions between these compounds that result in potentially stronger or weaker overall antifungal activity of the secretion were never studied before. The widely accepted way of measuring interaction, i.e., the checkerboard method, which is based on calculation of the fractional inhibitory concentration index, was used for this purpose. This index is expressed as the interaction of two agents where the concentration of each tested agent in combination is expressed as a fraction of the concentration that would produce the same effect when employed independently, and it is used to define the nature and type of interactions [Berenbaum, 1978; van Vuuren, Viljoen, 2011]. Both compounds when combined in various ratios required notably lower concentrations to suppress fungal growth than those recorded for individual MIC values. Most frequently, regardless of the tested fungal species, $p$-cresol and phenol produced a total effect that was equal to the sum of individual effects of the compounds, i.e., an additive effect, while a much greater effect of combination than the sum of effects of the individual compounds, i.e., a synergistic effect, was documented in only one instance in the case of $A$. niger. The rest of the tested combinations resulted in an indifferent effect of compounds.

Although our data point to the existence of synergism or additivism between $p$-cresol and phenol, our study also shows that indifference is usually present in mixtures with a higher proportion of $p$-cresol. Data obtained from such combinations are of interest because the defensive secretion of $A$. insculpta is characterized by the dominance of $p$-cresol. Thus, this type of interaction is present in the native defensive secretion of $A$. insculpta. However, we cannot generalize that only indifference exists between the two phenolics present in this callipodidan defensive secretion. Data from a previous study of ours [Ilić et al., 2019] indicate that the defensive secretion of $A$. insculpta has a stronger antifungal effect against two Candida species ( $C$. krusei and C. tropicalis) than $p$-cresol and phenol. The minimum fungicidal concentrations of the tested diplopod defensive secretion had three and six time lower values than either of the phenolics that constitute this secretion. In view of this result, it is apparent that a synergistic effect can also be present between $p$-cresol and phenol in the defensive secretion of $A$. insculpta.

Despite the fact that phenolic compounds are effective against various microorganisms, there are bacterial and fungal species that have the metabolic capability of using them as growth substrates [Alexieva et al., 2008; Gérecová et al., 2015 and references therein]. For example, some yeasts of the genera Rhodotorula, Trichosporon and Candida can metabolize phenolic compounds as a source for growth [Piakong et al., 2009; Karimi, Hasanshahian, 2016]. Utilization of phenolics as a substrate for growth can be achieved through several metabolic pathways. Specifically, phenol is degraded to catechol and further through a series of steps to succinate and acetyl coenzyme A via the catechol 
branch of the 3-oxoadipate pathway [Gérecová et al., 2015]. Degradation of $p$-cresol by several fungal species has also been recorded [Kennes, Lema, 1994; Alexieva et al., 2008]. Our data show that survival of the yeast $M$. guillermondii was not affected by $p$-cresol and phenol, or by different combinations of these two phenolics. This result can be explained by the fact that the fungal species in question has the ability to degrade phenol and use it as a source of carbon and energy [Karimi, Hasanshahian, 2016]. To our knowledge, there are no data indicating the ability of $M$. guillermondii to metabolize $p$-cresol, but we presume that this yeast can also survive and use $p$-cresol as a source for growth.

Both compounds of the defensive gland secretion of $A$. insculpta are structurally simple, but their biological activities can be diverse. In light of the knowledge that arthropod defensive secretions usually act parsimoniously [Blum et al., 1996], it would be interesting to test whether and how each compound (or class of chemical compounds) of the defensive secretion of $A$. insculpta (and other millipedes) contributes to biological interactions between millipedes and other organisms, especially in acting against pathogenic bacteria and various invertebrate and vertebrate predators.

Acknowledgements. This research was financially supported by the Ministry of Education, Science and Technological Development of the Republic of Serbia (Grant 451-03-68/ 2020-14/ 200178). The authors would like to thank Mr. Raymond Dooley for correcting the English of the manuscript.

\section{References}

Alexieva Z., Gerginova M., Manasiev J., Zlateva P., Shivarova N., Krastanov A. 2008. Phenol and cresol mixture degradation by the yeast Trichosporon cutaneum // Journal of Industrial Microbiology and Biotechnology. Vol.35. P.1297-1301.

Berenbaum M.C. 1978. A method for testing for synergy with any number of agents // The Journal of Infectious Diseases. Vol.137. No.2. P.122-130.

Berenbaum M.R. 1995. The chemistry of defense: theory and practice // Eisner T., Meinwald J. (eds.). Chemical ecology. The chemistry of biotic interaction. Washington, D.C.: National Academy Press. P.1-16.

Blum M.S. 1996. Semiochemical parsimony in the Arthropoda // Annual Review of Entomology. Vol.41. P.353-374.

Brocca A., Virzì G.M., de Cal M., Cantaluppi V., Ronco C. 2013. Cytotoxic effects of $p$-cresol in renal epithelial tubular cells // Blood Purification. Vol.36. P.219-225.

Ćurčić B., Makarov S., Tešević V., Jadranin M., Vujisić Lj. 2009. Identification of secretory compounds from the European callipodidan species Apfelbeckia insculpta // Journal of Chemical Ecology. Vol.35. No.8. P.893-895.

Dambolena J.S., Lopez A.G., Meriles J.M., Rubinstein H.R., Zygadlo J.A. 2012. Inhibitory effect of 10 natural phenolic compounds on Fusarium verticillioides. A structure-property-activity relationship study // Food Control. Vol.28. No.1. P.163-170.

Eisner T., Alsop D., Hicks K., Meinwald J. 1978. Defensive secretions of millipedes // Bettini S. (ed.). Arthropod Venoms. Handbook of Experimental Pharmacology. Vol.48. Springer, Berlin. P. 41-72.

Gallucci M.N., Carezzano M.E., Oliva M.M., Demo M.S., Pizzolitto R.P., Zunino M.P., Zygadlo J.A., Dambolena J.S. 2014. In vitro activity of natural phenolic compounds against fluconazole-resistant Candida species: a quantitative structure-activity relationship analysis // Journal of Applied Microbiology. Vol.116. No.4. P.795-804.
Gérecová G., Neboháèová, M., Zeman, I., Pryszcz L.P., Tomáška L., Gabaldón T., Nosek J. 2015. Metabolic gene clusters encoding the enzymes of two branches of the 3-oxoadipate pathway in the pathogenic yeast Candida albicans // FEMS Yeast Research.Vol.15. No.3. P.1-13.

Hopkin S.P., Read H.J. 1992. The biology of millipedes. Oxford: Oxford University Press. 246 pp.

Ilić B., Unković N., Ćirić A., Glamočlija J., Ljaljević Grbić M., Raspotnig G., Bodner M., Vukojević J., Makarov S. 2019. Phenol-based millipede defence: antimicrobial activity of secretions from the Balkan endemic millipede Apfelbeckia insculpta (L. Koch, 1867) (Diplopoda: Callipodida) // The Science of Nature. Vol.106. No.7-8.

Karimi M., Hassahshahian M. 2016. Isolation and characterization of phenol degrading yeasts from wastewater in the coking plant of Zarand, Kerman // Brazilian Journal of Microbiology. Vol.47. P.18-24.

Kennes C., Lema J.M. 1994. Simultaneous biodegradation of $p$-cresol and phenol by the basidiomycete Phanerochaete chrysosporium // Journal of Industrial Microbiology. Vol.13. No.5. P.311-314.

Koch M. 2015. Diplopoda - general morphology // Minelli A. (ed.). Treatise on zoology - anatomy, taxonomy, biology. The Myriapoda. Vol 2. Leiden: Koninklijke Brill NV. P.7-67.

Makarov S.E. 2015. Diplopoda - integument // A. Minelli (ed.). Treatise on zoology - anatomy, taxonomy, biology. The Myriapoda. Vol 2. Leiden: Koninklijke Brill NV. P.69-99.

Makarov S.E., Ćurčić B.P.M., Vujisić Lj.V., Jadranin M.B., Tešević V.V., Vučković I.M., Sekulić T.L., Ćurčić S.B., Mitić B.M. 2011. Defensive secretions in Callipodella fasciata (Latzel, 1882; Diplopoda, Callipodida, Schizopetalidae) // Chemistry \& Biodiversity. Vol.8. No.7. P.1284-1289.

Murakami Y., Kawata A., Ito S., Katayama T., Fujisawa S. 2014. Inhibitory effects of $p$-cresol and $p$-hydroxy anisole dimers on expression of the cyclooxygenase- 2 gene and lipopolysaccharide-stimulated activation of nuclear factor- $\kappa \mathrm{B}$ in RAW264.7 cells // In Vivo. Vol.28. No.5. P.719-726.

Piakong M.T., Noor Aini A.B., Madihah M.S. 2009. Degradation pathway of phenol through ortho-claevage by Candida tropicalis Rrtl-Cr1 // Borneo Science. Vol.24. P.1-8.

Pizzolitto R.P., Barberis C.L., Dambolena J.S., Herrera J.M., Zunino M.P., Magnoli C.E., Rubinstein H.R., Zygadlo J.A., Dalcero A.M. 2015. Inhibitory effect of natural phenolic compounds on Aspergillus parasiticus growth // Journal of Chemistry. Art.547925.

Rodriguez J., Jones T.H., Sierwlad P., Marek P.E., Shear W.A., Brewer M.S., Kocot K.M., Bond J.E. 2018. Step-wise evolution of complex chemical defenses in millipedes: a phylogenomic approach // Scientific Reports. Vol.8. No.1. Art.3209.

Roncardori R.W., Duffey S.S., Blum M.S. 1985. Antifungal activity of defensive secretions of certain millipedes // Mycologia. Vol.77. No.2. P.185-191.

Sabbineni J. 2016. Phenol - an effective antibacterial agent // Research \& Reviews: Journal of Medicinal \& Organic Chemistry. Vol.3. No.2. P.182-191.

Schwalbe R., Steele-Moore L., Goodwin A.C. 2007. Antimicrobial susceptibility testing protocols. USA: CRC Press.

Shear W.A. 2015. The chemical defenses of millipedes (Diplopoda): biochemistry, physiology and ecology // Biochemical Systematics and Ecology. Vol.61. P.78-117.

Shear W.A., McPherson I.S., Jones T.H., Loria S.F., Zigler K.S. 2010. Chemical defense of a troglobiont millipede, Tetracion jonesi Hoffman (Diplopoda: Callipodida: Abacionidae) // International Journal of Myriapodology. Vol.3. No.2. P.153-158.

Sierwald P., Bond J.E. 2007. Current status of the myriapod class Diplopoda (millipedes): taxonomic diversity and phylogeny // Annual Review of Entomology. Vol. 52. P.401-420.

van Vuuren S., Viljoen A. 2011. Plant-based antimicrobial studies methods and approaches to study the interaction between natural products // Planta Medica. Vol.77. No.11. P.1168-1182.

Velásquez P., Montenegro G., Giordano A., Retamal M., Valenzuela L.M. 2019. Bioactivities of phenolic blend extracts from Chilean honey and bee pollen // CYTA - Journal of Food. Vol.17. No.1. P.754-762.

Responsible editor S.I. Golovatch 